Article

\title{
Sex-Specific Catabolic Metabolism Alterations in the Critically Ill following High Dose Vitamin D
}

\author{
Sowmya Chary ${ }^{1}$, Karin Amrein ${ }^{2}$, Sherif H. Mahmoud ${ }^{3}{ }^{2}$, Jessica A. Lasky-Su ${ }^{4}$ \\ and Kenneth B. Christopher $4,5, *$ (B)
}

1 Biogen, Inc., Cambridge, MA 02142, USA; sowmyachary24@gmail.com

2 Division of Endocrinology and Diabetology, Medical University of Graz, 8036 Graz, Austria; karin.amrein@medunigraz.at

3 Faculty of Pharmacy and Pharmaceutical Sciences, University of Alberta, Edmonton, AB T6G 2R3, Canada; smahmoud@ualberta.ca

4 Channing Division of Network Medicine, Brigham and Women's Hospital, Harvard Medical School, Boston, MA 02115, USA; jessica.a.su@gmail.com

5 Division of Renal Medicine, Brigham and Women's Hospital, Harvard Medical School, Boston, MA 02115, USA

* Correspondence: kbchristopher@bwh.harvard.edu

check for

updates

Citation: Chary, S.; Amrein, K.;

Mahmoud, S.H.; Lasky-Su, J.A.;

Christopher, K.B. Sex-Specific

Catabolic Metabolism Alterations in

the Critically Ill following High Dose

Vitamin D. Metabolites 2022, 12, 207.

https://doi.org/10.3390/

metabo12030207

Academic Editors: Michele Mussap and Luigi Atzori

Received: 8 December 2021

Accepted: 24 February 2022

Published: 25 February 2022

Publisher's Note: MDPI stays neutral with regard to jurisdictional claims in published maps and institutional affiliations.

Copyright: (C) 2022 by the authors. Licensee MDPI, Basel, Switzerland. This article is an open access article distributed under the terms and conditions of the Creative Commons Attribution (CC BY) license (https:// creativecommons.org/licenses/by/ $4.0 /)$.

\begin{abstract}
Pharmacological interventions are essential for the treatment and management of critical illness. Although women comprise a large proportion of the critically ill, sex-specific pharmacological properties are poorly described in critical care. The sex-specific effects of vitamin $\mathrm{D}_{3}$ treatment in the critically ill are not known. Therefore, we performed a metabolomics cohort study with 1215 plasma samples from 428 patients from the VITdAL-ICU trial to study sex-specific differences in the metabolic response to critical illness following high-dose oral vitamin $\mathrm{D}_{3}$ intervention. In women, despite the dose of vitamin $\mathrm{D}_{3}$ being higher, pharmacokinetics demonstrated a lower extent of vitamin $\mathrm{D}_{3}$ absorption compared to men. Metabolic response to high-dose oral vitamin $\mathrm{D}_{3}$ is sex-specific. Sex-stratified individual metabolite associations with elevations in $25(\mathrm{OH}) \mathrm{D}$ following intervention showed female-specific positive associations in long-chain acylcarnitines and male-specific positive associations in free fatty acids. In subjects who responded to vitamin $\mathrm{D}_{3}$ intervention, significant negative associations were observed in short-chain acylcarnitines and branched chain amino acid metabolites in women as compared to men. Acylcarnitines and branched chain amino acids are reflective of fatty acid B oxidation, and bioenergesis may represent notable metabolic signatures of the sex-specific response to vitamin D. Demonstrating sex-specific pharmacometabolomics differences following intervention is an important movement towards the understanding of personalized medicine.
\end{abstract}

Keywords: sex; metabolomics; women; vitamin D; acylcarnitine; bioenergesis

\section{Introduction}

Women and men have dissimilar pharmacokinetics and pharmacodynamics in response to drug interventions [1]. In metabolism, sex-specific genetic differences are present [2,3]. Sizable studies on circulating metabolites in ambulatory patients show notable sex-specific differences [2-4]. Sex-specific pharmacological properties are poorly described and most drugs do not have specific dosage recommendations for women and men [5-7].

Critically ill patients have a profound disruption of systemic homeostasis, as reflected by circulating metabolites. Blood-based metabolomic studies early in critical illness can reflect dysregulated cellular byproducts, inform illness severity and be used to predict outcomes [8,9]. Metabolomic profiles are shown to differ in critically ill patients with and without low 25(OH)D levels [10]. Sex-specific differences are noted in 25(OH)D levels and immunomodulatory effects as well as cardiometabolic traits in ambulatory adults [11,12]. 
Though the pharmacokinetics is well described in outpatients, the sex-specific effects of high-dose vitamin $\mathrm{D}_{3}$ in the critically ill is not known [13-16].

Metabolomics before and after intervention can furnish mechanistic insight into drug response and severity of critical illness $[17,18]$. Sex-specific pharmacokinetics is likely present with oral medication use [19]. But, sex-specific pharmacometabolomics is poorly described, especially in critical care. Therefore, we studied sex-specific differences in the metabolic response to critical illness following high-dose oral vitamin $\mathrm{D}_{3}$. We hypothesize that significant sex-specific pharmacokinetic and metabolomic responses to vitamin $\mathrm{D}_{3}$ intervention exist.

We performed a post hoc metabolomics cohort study of 1215 plasma samples from 428 patients collected during the VITdAL-ICU trial [20]. The VITdAL-ICU trial was a single-center trial of 492 critically ill adults with 25-hydroxyvitamin D [25(OH)D] levels $\leq 20 \mathrm{ng} / \mathrm{mL}$ randomized to high-dose oral vitamin $\mathrm{D}_{3}$ or placebo [20]. The VITdAL-ICU trial was negative for the primary outcome of length of stay. In a secondary outcome, the VITdAL-ICU trial showed that in patients with low baseline vitamin D levels mortality was lower in patients who received high-dose oral vitamin $\mathrm{D}_{3}$ compared to those who received placebo [20]. We assessed the sex-specific changes in individual metabolites following high-dose vitamin D intervention in critical illness. Secondly, we determined if sex-specific differences in pharmacokinetics or mediation exist of the relationship between the response to intervention and individual metabolite change.

\section{Results}

\subsection{Demographics}

Baseline characteristics were similar between groups of subjects stratified by absolute increase in $25(\mathrm{OH}) \mathrm{D} \geq 7.5 \mathrm{ng} / \mathrm{mL}$ between day 0 and 3 and then sex for SAPS II, C-reactive protein, baseline $25(\mathrm{OH}) \mathrm{D}$, body mass index (BMI), diabetes and ICU type. Differences existed with respect to age, Charlson Comorbidity Index, intervention status, change in $25(\mathrm{OH}) \mathrm{D}$ and day 0 levels of glucose (Table 1). The overall 28-day mortality of the 428 subject analytic cohort was $22.2 \%$. Twenty-eight-day mortality differed based on absolute increase in $25(\mathrm{OH}) \mathrm{D}$ levels between day 0 and day $3(x 2(1)=13.3 ; p<0.001)$ but not gender $(\chi 2(1)=0.014 ; p=0.91)$.

\subsection{Pharmacokinetics}

We next evaluated the sex-specific pharmacokinetics of high-dose oral vitamin $\mathrm{D}_{3}$. The amount of vitamin $\mathrm{D}_{3}$ administered was the same in men and women (oral 540,000 IU vitamin $\left.\mathrm{D}_{3}\right)$; the dose of vitamin $\mathrm{D}_{3}(\mathrm{IU} / \mathrm{kg})$, in general, is higher in women due to their lower body weight. Despite different IU $/ \mathrm{kg}$ doses, the pharmacokinetics of $25(\mathrm{OH}) \mathrm{D}$ in patients randomized to vitamin $\mathrm{D}_{3}$ showed similar mean serum $25(\mathrm{OH}) \mathrm{D}$ concentrations over time (Table S1, Figure S1). Compared with women, the pharmacokinetic parameters of 25(OH)D using non-compartmental analysis showed significantly higher normalized AUC0-7 in men $(p<0.05)$, a measure of the extent of drug absorption.

\subsection{Sex-Stratified Analyses}

In day 0 plasma samples of female subjects $(N=151)$, no significant differences were found in any individual metabolites by $t$-test (all $q$-values $>0.10$ ) (Table S2) or in metabolomic profiles by OPLS-DA (CV-ANOVA, $p=0.99)$ in subjects with an increase of $25(\mathrm{OH}) \mathrm{D}<$ or $\geq 7.5 \mathrm{ng} / \mathrm{mL}$ from day 0 to day 3 (Table S3). In male subjects at day 0 $(\mathrm{N}=277)$, no significant differences in individual metabolites were found by $t$-test (all $q$-values $>0.10$ ) (Table S2) or in metabolomic profiles as determined by OPLS-DA (CVANOVA, $p$-value 0.99$)$ in those with an increase in $25(\mathrm{OH}) \mathrm{D} \geq 7.5 \mathrm{ng} / \mathrm{mL}$ from day 0 to 3 relative to subjects who did not (Table S3). 
Table 1. Characteristics of analytic cohort, according to sex and 25(OH)D response.

\begin{tabular}{|c|c|c|c|c|c|c|}
\hline \multirow{3}{*}{ Characteristic } & \multicolumn{4}{|c|}{ Absolute Increase in 25(OH)D Level between Day 0 and Day 3} & \multirow{3}{*}{ Total } & \multirow{3}{*}{$p$-Value } \\
\hline & \multicolumn{2}{|c|}{$25(\mathrm{OH}) \mathrm{D} \geq 7.5 \mathrm{ng} / \mathrm{mL}$} & \multicolumn{2}{|c|}{$25(\mathrm{OH}) \mathrm{D}<7.5 \mathrm{ng} / \mathrm{mL}$} & & \\
\hline & Female & Male & Female & Male & & \\
\hline No. & 59 & 97 & 92 & 180 & 428 & \\
\hline Age (Years) Mean (SD) & $66.5(15.6)$ & $63.3(16.4)$ & $69.3(11.5)$ & $61.2(14.7)$ & $64.2(14.9)$ & $<0.001 *$ \\
\hline SAPS II Mean (SD) & $34.0(16.2)$ & $33.0(17.0)$ & 34.9 (13.8) & $32.5(15.1)$ & $33.4(15.4)$ & $0.67^{*}$ \\
\hline $\begin{array}{l}\text { CRP } \mu \mathrm{g} / \mathrm{mL} \text { Day } 0 \text { Mean } \\
\text { (SD) }\end{array}$ & $125.9(101.8)$ & $125.2(93.6)$ & $116.0(93.2)$ & $128.9(81.9)$ & $124.9(89.8)$ & 0.74 * \\
\hline $\begin{array}{l}\text { Day } 0 \text { 25(OH)D ng/mL } \\
\text { Mean (SD) }\end{array}$ & $12.5(4.5)$ & $15.6(15.7)$ & $13.6(6.4)$ & $13.7(4.9)$ & $14(8.8)$ & $0.15^{*}$ \\
\hline $\begin{array}{l}\text { Vitamin } \mathrm{D}_{3} \text { Intervention } \\
\text { No. }(\%)\end{array}$ & $57(97)$ & $96(99)$ & $21(23)$ & $38(21)$ & $212(50)$ & $<0.001$ \\
\hline $\begin{array}{l}\text { Change in } 25(\mathrm{OH}) \mathrm{D} \\
\mathrm{ng} / \mathrm{mL} \text { Median (IQR) }\end{array}$ & $22.3[14.7,37.1]$ & $22.2[14.7,38.2]$ & $0.5[-1.6,2.5]$ & $0.6[-1.2,2.9]$ & $3.3[0,16.7]$ & $<0.001 \ddagger$ \\
\hline BMI Mean (SD) & $26.7(4.8)$ & $27.2(4.6)$ & $27.5(5.8)$ & $26.9(5.4)$ & $27.1(5.2)$ & $0.75 *$ \\
\hline $\begin{array}{l}\text { Charlson Comorbidity } \\
\text { Index Mean (SD) }\end{array}$ & $2.2(1.6)$ & $3.1(2.4)$ & $3.2(2.1)$ & $3.0(2.2)$ & $3.0(2.2)$ & $<0.001 *$ \\
\hline Diabetes History No. (\%) & $15(25)$ & $19(20)$ & $24(26)$ & $43(24)$ & $101(24)$ & 0.73 \\
\hline Glucose Day 0 Mean (SD) & $167.7(64.5)$ & $147.5(46.1)$ & $153.5(50.7)$ & $144.2(48.5)$ & $150.3(51.4)$ & $0.025 *$ \\
\hline ICU & & & & & & 0.13 \\
\hline Anesthesia ICU No. (\%) & $10(17)$ & $15(16)$ & $14(15)$ & $42(24)$ & $81(19)$ & \\
\hline $\begin{array}{l}\text { Cardiac Surgery ICU } \\
\text { No. }(\%)\end{array}$ & $13(22)$ & $24(25)$ & $27(30)$ & $59(33)$ & $123(29)$ & \\
\hline Medicine ICU No. (\%) & $12(21)$ & $19(20)$ & $19(21)$ & $39(22)$ & $89(21)$ & \\
\hline Neurological ICU No. (\%) & $21(36)$ & $30(32)$ & $26(29)$ & $29(16)$ & $106(25)$ & \\
\hline Surgical No. (\%) & $2(3)$ & $7(7)$ & $5(5)$ & $8(5)$ & $22(5)$ & \\
\hline 28-day Mortality No. (\%) & $11(19)$ & $11(11)$ & $23(25)$ & $50(28)$ & $95(22)$ & 0.013 \\
\hline
\end{tabular}

In sex-stratified mixed effects modeling of day 0,3 and 7 plasma samples in 151 women (435 total samples) and 277 men (795 total samples), sex-specific differences were present, with increases in 25(OH)D between day 0 and day 3. Significant increases in long-chain acylcarnitines with elevated $25(\mathrm{OH}) \mathrm{D}$ were seen only in the female stratum (summary of data presented in Table 2, Figure 1; full data presented in Table S4). In the male but not the female stratum, significant negative associations were found with ceramides, dicarboxylate fatty acids and long chain fatty acids in the setting of increasing 25(OH)D (summarized data in Table 3, Figure 2; full data in Table S4). The common response in both the female and male strata to elevations in $25(\mathrm{OH}) \mathrm{D}$ is significantly increased branched chain amino acid (BCAA) metabolism and plasmalogens as well as decreases in pentose phosphate pathway metabolites (Table 4; full data in Table S4). In the sex-stratified mixed effects regression, additional adjustment for the Charlson Comorbidity Index did not materially alter the direction and effect size of the associations between sex and metabolite pathways (Table S5). 
Table 2. Long-chain acylcarnitines significantly associated with response to high-dose vitamin $\mathrm{D}$ in women but not men.

\begin{tabular}{|c|c|c|c|c|c|c|c|}
\hline \multirow{2}{*}{ Metabolite } & \multicolumn{3}{|c|}{ Female Stratum } & \multicolumn{3}{|c|}{ Male Stratum } & \multirow{2}{*}{ Sub-Pathway } \\
\hline & $\beta$ Coefficient & $p$-Value & $q$-Value & $\beta$ Coefficient & $p$-Value & $q$-Value & \\
\hline $\begin{array}{l}\text { Palmitoylcarnitine } \\
\text { (C16) }\end{array}$ & 0.004593 & $2.65 \times 10^{-3}$ & $5.83 \times 10^{-2}$ & -0.00156 & $2.76 \times 10^{-1}$ & $4.96 \times 10^{-1}$ & $\begin{array}{l}\text { Long-chain } \\
\text { Acylcarnitine }\end{array}$ \\
\hline $\begin{array}{l}\text { Margaroylcarnitine } \\
(\mathrm{C} 17)^{*}\end{array}$ & 0.005591 & $1.19 \times 10^{-3}$ & $5.27 \times 10^{-2}$ & -0.0007 & $6.47 \times 10^{-1}$ & $7.81 \times 10^{-1}$ & $\begin{array}{l}\text { Long-chain } \\
\text { Acylcarnitine }\end{array}$ \\
\hline $\begin{array}{l}\text { Stearoylcarnitine } \\
\text { (C18) }\end{array}$ & 0.006447 & $1.08 \times 10^{-5}$ & $7.89 \times 10^{-3}$ & 0.0000581 & $9.67 \times 10^{-1}$ & $9.81 \times 10^{-1}$ & $\begin{array}{l}\text { Long-chain } \\
\text { Acylcarnitine }\end{array}$ \\
\hline $\begin{array}{l}\text { Linoleoylcarnitine } \\
(\mathrm{C} 18: 2)^{*}\end{array}$ & 0.004122 & $1.11 \times 10^{-2}$ & $9.81 \times 10^{-2}$ & 0.001059 & $4.35 \times 10^{-1}$ & $6.29 \times 10^{-1}$ & $\begin{array}{l}\text { Long-chain } \\
\text { Acylcarnitine }\end{array}$ \\
\hline $\begin{array}{l}\text { Dihomo- } \\
\text { linolenoylcarnitine } \\
(\mathrm{C} 20: 3 \mathrm{n} 3 \text { or } 6)^{*}\end{array}$ & 0.005715 & $7.64 \times 10^{-4}$ & $4.15 \times 10^{-2}$ & 0.001106 & $4.73 \times 10^{-1}$ & $6.55 \times 10^{-1}$ & $\begin{array}{l}\text { Long-chain } \\
\text { Acylcarnitine }\end{array}$ \\
\hline $\begin{array}{l}\text { Arachidonoylcarnitine } \\
\text { (C20:4) }\end{array}$ & 0.004813 & $6.21 \times 10^{-3}$ & $7.59 \times 10^{-2}$ & 0.001038 & $5.10 \times 10^{-1}$ & $6.78 \times 10^{-1}$ & $\begin{array}{l}\text { Long-chain } \\
\text { Acylcarnitine }\end{array}$ \\
\hline $\begin{array}{l}\text { Arachidoylcarnitine } \\
(\mathrm{C} 20)^{*}\end{array}$ & 0.004313 & $1.21 \times 10^{-2}$ & $9.89 \times 10^{-2}$ & 0.000811 & $5.71 \times 10^{-1}$ & $7.29 \times 10^{-1}$ & $\begin{array}{l}\text { Long-chain } \\
\text { Acylcarnitine }\end{array}$ \\
\hline $\begin{array}{l}\text { Adrenoylcarnitine } \\
(\mathrm{C} 22: 4)^{*}\end{array}$ & 0.00495 & $5.79 \times 10^{-3}$ & $7.59 \times 10^{-2}$ & 0.001161 & $4.98 \times 10^{-1}$ & $6.68 \times 10^{-1}$ & $\begin{array}{l}\text { Long-chain } \\
\text { Acylcarnitine }\end{array}$ \\
\hline $\begin{array}{l}\text { Lignoceroylcarnitine } \\
(\mathrm{C} 24)^{*}\end{array}$ & 0.004725 & $1.17 \times 10^{-3}$ & $5.27 \times 10^{-2}$ & -0.00017 & $9.02 \times 10^{-1}$ & $9.43 \times 10^{-1}$ & $\begin{array}{l}\text { Long-chain } \\
\text { Acylcarnitine }\end{array}$ \\
\hline $\begin{array}{l}\text { Cerotoylcarnitine } \\
(\mathrm{C} 26)^{*}\end{array}$ & 0.004831 & $1.86 \times 10^{-3}$ & $5.50 \times 10^{-2}$ & 0.000254 & $8.68 \times 10^{-1}$ & $9.21 \times 10^{-1}$ & $\begin{array}{l}\text { Long-chain } \\
\text { Acylcarnitine }\end{array}$ \\
\hline
\end{tabular}

Note: Mixed effects modeling results for selected metabolites significant in women. For day 0, 3 and 7 repeated measures data, correlations between individual metabolites and absolute increase in 25(OH)D levels from day 0 to 3 were determined separately in women $(N=151)$ and in men $(N=277)$ utilizing linear mixed effects models correcting for age, baseline $25(\mathrm{OH}) \mathrm{D}$, absolute increase in $25(\mathrm{OH}) \mathrm{D}$ at day 3, SAPS II, sample day, admission diagnosis and an individual subject-specific random intercept. Bolded $q$-value results indicate statistical significance following false discovery rate (FDR) adjustment to $0.10{ }^{*}$ metabolites are identified via predictive or externally acquired structure evidence when a reference standard does not exist.

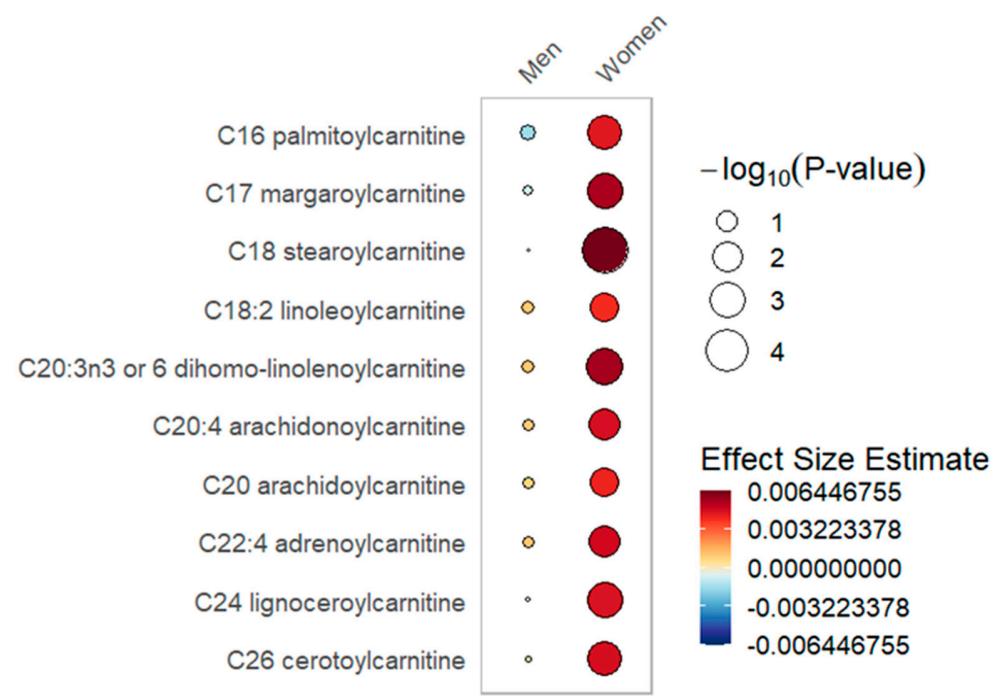

Figure 1. Long-chain acylcarnitines rain plot. Correlations between absolute increase in $25(\mathrm{OH}) \mathrm{D}$ levels from day 0 to day 3 and individual long-chain acylcarnitine metabolite abundance at day 0,3 or 7 in women or men determined utilizing mixed-effects linear regression models correcting for age, SAPS II, admission diagnosis and $25(\mathrm{OH}) \mathrm{D}$ at day 0 . The red color fill scare indicates the magnitude of beta coefficient estimates and the size of the circle corresponds to the significance level $\left(-\log _{10}(p\right.$-value $\left.)\right)$. Statistical significance is the multiple test-corrected threshold of $-\log _{10}(p)>1.92$ which is equivalent to $p<0.0122$. 
Table 3. Free fatty acid metabolites significantly associated with responses to high-dose vitamin $\mathrm{D}$ in men but not women.

\begin{tabular}{|c|c|c|c|c|c|c|c|}
\hline \multirow{2}{*}{ Metabolite } & \multicolumn{3}{|c|}{ Female Stratum } & \multicolumn{3}{|c|}{ Male Stratum } & \multirow{2}{*}{ Sub-Pathway } \\
\hline & $\beta$ Coefficient & $p$-Value & $q$-Value & $\beta$ Coefficient & $p$-Value & $q$-Value & \\
\hline $\begin{array}{l}\text { Ceramide } \\
\text { (d18:1/17:0, } \\
\text { d17:1/18:0) * }\end{array}$ & -0.00018 & $9.15 \times 10^{-1}$ & $9.60 \times 10^{-1}$ & -0.00487 & $1.84 \times 10^{-3}$ & $4.49 \times 10^{-2}$ & Ceramide \\
\hline $\begin{array}{l}\text { N-stearoyl- } \\
\text { sphingosine } \\
(\mathrm{d} 18: 1 / 18: 0)^{*}\end{array}$ & -0.00159 & $3.62 \times 10^{-1}$ & $5.96 \times 10^{-1}$ & -0.00494 & $1.59 \times 10^{-3}$ & $4.08 \times 10^{-2}$ & Ceramide \\
\hline $\begin{array}{l}\text { N-palmitoyl- } \\
\text { sphingosine } \\
\text { (d18:1/16:0) }\end{array}$ & -0.00208 & $1.87 \times 10^{-1}$ & $4.10 \times 10^{-1}$ & -0.00496 & $9.80 \times 10^{-4}$ & $2.95 \times 10^{-2}$ & Ceramide \\
\hline $\begin{array}{l}\text { N-stearoyl- } \\
\text { sphingadienine } \\
(\mathrm{d} 18: 2 / 18: 0)^{*}\end{array}$ & -0.00199 & $2.73 \times 10^{-1}$ & $5.08 \times 10^{-1}$ & -0.00525 & $6.44 \times 10^{-4}$ & $2.28 \times 10^{-2}$ & Ceramide \\
\hline Suberate (C8-DC) & -0.00435 & $1.79 \times 10^{-2}$ & $1.23 \times 10^{-1}$ & -0.00513 & $6.47 \times 10^{-3}$ & $7.18 \times 10^{-2}$ & $\begin{array}{c}\text { Fatty Acid, } \\
\text { Dicarboxylate }\end{array}$ \\
\hline $\begin{array}{l}\text { Heptenedioate } \\
(\mathrm{C} 7: 1-\mathrm{DC})^{*}\end{array}$ & -0.00161 & $5.08 \times 10^{-1}$ & $7.24 \times 10^{-1}$ & -0.00535 & $1.27 \times 10^{-2}$ & $9.53 \times 10^{-2}$ & $\begin{array}{c}\text { Fatty Acid, } \\
\text { Dicarboxylate }\end{array}$ \\
\hline 3-methyladipate & -0.00469 & $3.39 \times 10^{-2}$ & $1.62 \times 10^{-1}$ & -0.00648 & $5.36 \times 10^{-3}$ & $6.71 \times 10^{-2}$ & $\begin{array}{c}\text { Fatty Acid, } \\
\text { Dicarboxylate }\end{array}$ \\
\hline 2-hydroxyadipate & -0.00377 & $8.30 \times 10^{-2}$ & $2.65 \times 10^{-1}$ & -0.00652 & $5.18 \times 10^{-3}$ & $6.65 \times 10^{-2}$ & $\begin{array}{c}\text { Fatty Acid, } \\
\text { Dicarboxylate }\end{array}$ \\
\hline 3-hydroxyadipate * & -0.00247 & $3.31 \times 10^{-1}$ & $5.68 \times 10^{-1}$ & -0.00837 & $3.84 \times 10^{-4}$ & $1.72 \times 10^{-2}$ & $\begin{array}{c}\text { Fatty Acid, } \\
\text { Dicarboxylate }\end{array}$ \\
\hline Arachidate (20:0) & -0.00073 & $5.61 \times 10^{-1}$ & $7.56 \times 10^{-1}$ & -0.00287 & $7.31 \times 10^{-3}$ & $7.28 \times 10^{-2}$ & $\begin{array}{l}\text { Long Chain } \\
\text { Fatty Acid }\end{array}$ \\
\hline $\begin{array}{l}\text { Oleate/vaccenate } \\
(18: 1)\end{array}$ & -0.00063 & $6.90 \times 10^{-1}$ & $8.42 \times 10^{-1}$ & -0.00357 & $6.20 \times 10^{-3}$ & $7.18 \times 10^{-2}$ & $\begin{array}{l}\text { Long Chain } \\
\text { Fatty Acid }\end{array}$ \\
\hline $\begin{array}{l}\text { Eicosenoate (20:1n9 } \\
\text { or } 1 \mathrm{n} 11)\end{array}$ & -0.00109 & $5.16 \times 10^{-1}$ & $7.28 \times 10^{-1}$ & -0.00383 & $6.73 \times 10^{-3}$ & $7.28 \times 10^{-2}$ & $\begin{array}{l}\text { Long Chain } \\
\text { Fatty Acid }\end{array}$ \\
\hline Erucate (22:1n9) & -0.00221 & $1.72 \times 10^{-1}$ & $3.90 \times 10^{-1}$ & -0.00553 & $5.62 \times 10^{-5}$ & $7.48 \times 10^{-3}$ & $\begin{array}{l}\text { Long Chain } \\
\text { Fatty Acid }\end{array}$ \\
\hline $\begin{array}{l}\text { Docosapentaenoate } \\
(22: 5 \mathrm{n} 3)\end{array}$ & -0.00108 & $5.60 \times 10^{-1}$ & $7.55 \times 10^{-1}$ & -0.00391 & $9.29 \times 10^{-3}$ & $8.36 \times 10^{-2}$ & $\begin{array}{l}\text { Polyunsaturated } \\
\text { Fatty Acid }\end{array}$ \\
\hline $\begin{array}{l}\text { Eicosapentaenoate } \\
(20: 5 \mathrm{n} 3)\end{array}$ & -0.00402 & $5.46 \times 10^{-2}$ & $2.10 \times 10^{-1}$ & -0.00503 & $1.07 \times 10^{-2}$ & $8.94 \times 10^{-2}$ & $\begin{array}{l}\text { Polyunsaturated } \\
\text { Fatty Acid }\end{array}$ \\
\hline $\begin{array}{l}\text { Stearidonate } \\
(18: 4 \mathrm{n} 3)\end{array}$ & -0.00428 & $8.68 \times 10^{-2}$ & $2.70 \times 10^{-1}$ & -0.00595 & $7.82 \times 10^{-3}$ & $7.63 \times 10^{-2}$ & $\begin{array}{l}\text { Polyunsaturated } \\
\text { Fatty Acid }\end{array}$ \\
\hline $\begin{array}{l}\text { Docosatrienoate } \\
(22: 3 n 6)^{*}\end{array}$ & -0.00118 & $5.86 \times 10^{-1}$ & $7.67 \times 10^{-1}$ & -0.00759 & $6.13 \times 10^{-5}$ & $7.48 \times 10^{-3}$ & $\begin{array}{l}\text { Polyunsaturated } \\
\text { Fatty Acid }\end{array}$ \\
\hline
\end{tabular}

Note: Mixed effects modeling results for selected metabolites significant in men. For day 0, 3 and 7 repeated measures data, correlations between individual metabolites and absolute increase in 25(OH)D levels from day 0 to 3 were determined separately in women $(\mathrm{N}=151)$ and in men $(\mathrm{N}=277)$ utilizing linear mixed effects models correcting for age, baseline $25(\mathrm{OH}) \mathrm{D}$, absolute increase in $25(\mathrm{OH}) \mathrm{D}$ at day 3 , SAPS II, sample day, admission diagnosis, and an individual subject-specific random intercept. Bolded $q$-value results indicate statistical significance following false discovery rate (FDR) adjustment to $0.10 .{ }^{*}$ metabolites are identified via predictive or externally acquired structure evidence when a reference standard does not exist. 


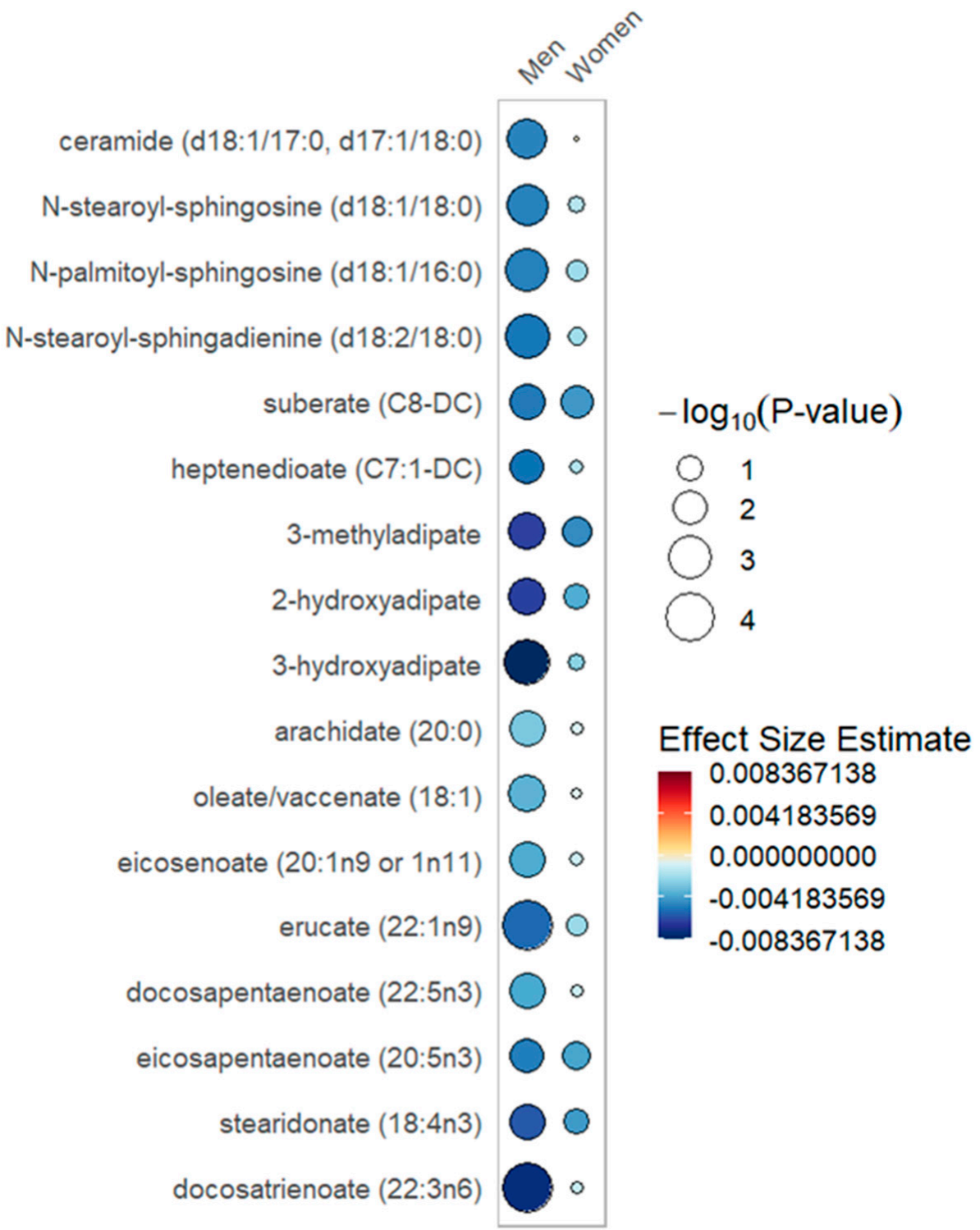

Figure 2. Free fatty acid metabolites rain plot. Correlations between absolute increase in $25(\mathrm{OH}) \mathrm{D}$ levels from day 0 to day 3 and individual free fatty acid metabolite abundance at day 0, 3 or 7 in women or men determined utilizing mixed-effects linear regression models correcting for age, SAPS II, admission diagnosis and $25(\mathrm{OH}) \mathrm{D}$ at day 0 . The blue color fill scare indicates the magnitude of beta coefficient estimates and the size of the circle corresponds to the significance level $\left(-\log _{10}(p\right.$-value $)$. Statistical significance is the multiple test-corrected threshold of $-\log _{10}(p)>1.92$, which is equivalent to $p<0.0122$.

\subsection{Responder Cohort Analysis}

Restricting the mixed effects modeling of day 0, 3 and 7 plasma samples to the 153-patient responder cohort (those who received high dose vitamin $\mathrm{D}_{3}$ intervention and had an increase in $25(\mathrm{OH}) \mathrm{D} \geq 7.5 \mathrm{ng} / \mathrm{mL}$ ) shows sex-specific metabolite patterns over time. Compared to men, women had lower levels of BCAA metabolites and short-chain acylcarnitines and higher levels of sphingomyelin species (Table S6, Figures S2 and S3). In the mixed effects regression of the responder cohort, additional adjustment for the Charlson Comorbidity Index did not change the direction, strength or significance of the associations between sex and metabolite pathways (Table S7). 
Table 4. Metabolites significantly associated with response to a high dose of vitamin D in both women and men.

\begin{tabular}{|c|c|c|c|c|c|c|c|}
\hline \multirow{2}{*}{ Metabolite } & \multicolumn{3}{|c|}{ Female Stratum } & \multicolumn{3}{|c|}{ Male Stratum } & \multirow{2}{*}{ Sub-Pathway } \\
\hline & $\beta$ Coefficient & $p$-Value & $q$-Value & $\beta$ Coefficient & $p$-Value & $q$-Value & \\
\hline $\begin{array}{l}\text { 3-methyl-2- } \\
\text { oxovalerate }\end{array}$ & 0.00454 & $4.82 \times 10^{-4}$ & $3.05 \times 10^{-2}$ & 0.00372 & $2.47 \times 10^{-3}$ & $5.24 \times 10^{-2}$ & $\begin{array}{c}\text { BCAA } \\
\text { Metabolism }\end{array}$ \\
\hline $\begin{array}{l}\text { 4-methyl-2- } \\
\text { oxopentanoate }\end{array}$ & 0.00357 & $1.02 \times 10^{-2}$ & $9.48 \times 10^{-2}$ & 0.00370 & $3.78 \times 10^{-3}$ & $5.98 \times 10^{-2}$ & $\begin{array}{c}\text { BCAA } \\
\text { Metabolism }\end{array}$ \\
\hline Leucine & 0.00293 & $4.96 \times 10^{-3}$ & $7.24 \times 10^{-2}$ & 0.00372 & $2.41 \times 10^{-4}$ & $1.34 \times 10^{-2}$ & $\begin{array}{c}\text { BCAA } \\
\text { Metabolism }\end{array}$ \\
\hline Isoleucine & 0.00293 & $5.01 \times 10^{-3}$ & $7.24 \times 10^{-2}$ & 0.00313 & $3.32 \times 10^{-4}$ & $1.62 \times 10^{-2}$ & $\begin{array}{c}\text { BCAA } \\
\text { Metabolism }\end{array}$ \\
\hline $\begin{array}{l}\text { 1-(1-enyl-stearoyl)-2- } \\
\text { arachidonoyl-GPE } \\
(\mathrm{P}-18: 0 / 20: 4) *\end{array}$ & 0.00708 & $1.61 \times 10^{-5}$ & $7.89 \times 10^{-3}$ & 0.00563 & $1.17 \times 10^{-4}$ & $1.16 \times 10^{-2}$ & Plasmalogen \\
\hline $\begin{array}{l}\text { 1-(1-enyl-stearoyl)-2- } \\
\text { linoleoyl-GPE } \\
(\mathrm{P}-18: 0 / 18: 2) \text { * }\end{array}$ & 0.00559 & $2.93 \times 10^{-4}$ & $2.38 \times 10^{-2}$ & 0.00514 & $1.66 \times 10^{-5}$ & $5.39 \times 10^{-3}$ & Plasmalogen \\
\hline $\begin{array}{l}\text { 1-(1-enyl-palmitoyl)- } \\
\text { 2-linoleoyl-GPE } \\
(\mathrm{P}-16: 0 / 18: 2) *\end{array}$ & 0.00551 & $2.03 \times 10^{-3}$ & $5.50 \times 10^{-2}$ & 0.00693 & $3.95 \times 10^{-6}$ & $2.14 \times 10^{-3}$ & Plasmalogen \\
\hline $\begin{array}{l}\text { 1-(1-enyl-palmitoyl)- } \\
\text { 2-arachidonoyl-GPE } \\
(\mathrm{P}-16: 0 / 20: 4) *\end{array}$ & 0.00484 & $5.14 \times 10^{-4}$ & $3.05 \times 10^{-2}$ & 0.00438 & $2.48 \times 10^{-4}$ & $1.34 \times 10^{-2}$ & Plasmalogen \\
\hline $\begin{array}{l}\text { 1-(1-enyl-palmitoyl)- } \\
\text { 2-arachidonoyl-GPC } \\
(\mathrm{P}-16: 0 / 20: 4) *\end{array}$ & 0.00465 & $2.45 \times 10^{-3}$ & $5.76 \times 10^{-2}$ & 0.00522 & $1.20 \times 10^{-4}$ & $1.16 \times 10^{-2}$ & Plasmalogen \\
\hline $\begin{array}{l}\text { 1-(1-enyl-palmitoyl)- } \\
\text { 2-linoleoyl-GPC } \\
(\mathrm{P}-16: 0 / 18: 2) *\end{array}$ & 0.00448 & $4.58 \times 10^{-3}$ & $7.01 \times 10^{-2}$ & 0.00434 & $2.47 \times 10^{-3}$ & $5.24 \times 10^{-2}$ & Plasmalogen \\
\hline $\begin{array}{l}\text { 1-(1-enyl-palmitoyl)- } \\
\text { 2-palmitoyl-GPC } \\
(\mathrm{P}-16: 0 / 16: 0) *\end{array}$ & 0.00414 & $2.43 \times 10^{-4}$ & $2.22 \times 10^{-2}$ & 0.00414 & $2.43 \times 10^{-4}$ & $1.34 \times 10^{-2}$ & Plasmalogen \\
\hline Ribitol & -0.00464 & $1.01 \times 10^{-2}$ & $9.48 \times 10^{-2}$ & -0.00395 & $6.71 \times 10^{-3}$ & $7.28 \times 10^{-2}$ & $\begin{array}{c}\text { Pentose } \\
\text { Metabolism }\end{array}$ \\
\hline Gluconate & -0.00940 & $5.22 \times 10^{-3}$ & $7.40 \times 10^{-2}$ & -0.01015 & $5.30 \times 10^{-4}$ & $2.15 \times 10^{-2}$ & $\begin{array}{c}\text { Pentose } \\
\text { Metabolism }\end{array}$ \\
\hline Arabitol/xylitol & -0.00628 & $2.01 \times 10^{-3}$ & $5.50 \times 10^{-2}$ & -0.00463 & $6.97 \times 10^{-3}$ & $7.28 \times 10^{-2}$ & $\begin{array}{c}\text { Pentose } \\
\text { Metabolism }\end{array}$ \\
\hline
\end{tabular}

Note: Mixed effects modeling results of selected metabolites significant in both women and men. For day 0, 3 and 7 repeated measures data, correlations between individual metabolites and absolute increase in $25(\mathrm{OH}) \mathrm{D}$ levels from day 0 to 3 were determined separately in women $(\mathrm{N}=151)$ and in men $(\mathrm{N}=277)$ utilizing linear mixed effects models correcting for age, baseline $25(\mathrm{OH}) \mathrm{D}$, absolute increase in $25(\mathrm{OH}) \mathrm{D}$ at day 3 , SAPS II, sample day, admission diagnosis, and an individual subject-specific random intercept. Bolded $q$-value results indicate statistical significance following false discovery rate (FDR) adjustment to $0.10 .{ }^{*}$ metabolites are identified via predictive or externally acquired structure evidence when a reference standard does not exist.

\subsection{Mediation Analysis}

Finally, we focused on the potential mediation by sex of the relationship between metabolite abundance and absolute increase in $25(\mathrm{OH}) \mathrm{D}$ level between day 0 and day 3. Mediation analyses in day 3 data revealed no sex-dependent influence on associations between the absolute increase in 25(OH)D and all 983 metabolites (all mediation $p$-values were $>0.01$ ). As both adiposity and critical illness increase free fatty acids [21,22], we evaluated $\mathrm{BMI}$ as a sex-specific mediator of response to vitamin $\mathrm{D}_{3}$. When individually restricted to female $(N=151)$ or to male subjects $(N=277)$, mediation analyses of the day 3 data revealed no influence of BMI on associations between the absolute increase in 25(OH)D and all 983 metabolites (all mediation $p$-values were $>0.01$ ). 


\section{Discussion}

Our large post hoc metabolomics study considered temporal changes in the metabolome and $25(\mathrm{OH}) \mathrm{D}$ concentration as well as vitamin $\mathrm{D}_{3}$ dose to determine sex-specific differences in response to vitamin $D_{3}$ intervention. We evaluated the response to vitamin $D_{3}$ intervention in three ways: (1) a sex-specific pharmacokinetics study; (2) sex stratification to study metabolite differences relative to the change in $25(\mathrm{OH}) \mathrm{D}$ in women separately from metabolite differences in men; and (3) a responder cohort sub-analysis to directly compare metabolite differences between women and men who received vitamin $\mathrm{D}_{3}$ intervention and responded with an absolute increase in $25(\mathrm{OH}) \mathrm{D} \geq 7.5 \mathrm{ng} / \mathrm{mL}$ between day 0 and 3. Our approach to evaluate sex-specific responses resulted in novel findings. First, our pharmacokinetics data identified sex-specific differences in vitamin $\mathrm{D}_{3}$ absorption. Second, we showed a sex-specific metabolomic response to vitamin $\mathrm{D}_{3}$ associated with differential metabolite patterns over time early in the course of critical illness. These analyses demonstrate evidence of sex-specific metabolism following high-dose vitamin $\mathrm{D}_{3}$.

In the sex-stratified analysis, significant associations with long-chain acylcarnitines and increased 25(OH)D over day 0 to 3 were noted within the female stratum but not in the male stratum (Table 2, Figure 1). With increased $25(\mathrm{OH}) \mathrm{D}$, a significantly lower abundance of ceramides, dicarboxylate fatty acids and long chain fatty acids was limited to the male stratum (Table 3, Figure 2). Furthermore, the male but not the female stratum showed significant decreases in polyunsaturated fatty acids with increased $25(\mathrm{OH}) \mathrm{D}$ (Table 3, Figure 2). The common response to increased $25(\mathrm{OH}) \mathrm{D}$ in both female and male strata was a significant increase in plasmalogens and BCAA metabolites as well as a decrease in pentose phosphate pathway metabolites (Table S4). In the responder cohort data directly comparing metabolite differences in women and men who received and responded to high-dose vitamin $\mathrm{D}_{3}(\mathrm{~N}=153)$, we note that circulating BCAA metabolites and short-chain acylcarnitines are both significantly lower in women compared to men (Table S5).

To understand the relevance of the sex-specific metabolite patterns we observed, existing studies provide context. At homeostasis, metabolism, as well as drug pharmacokinetics and pharmacodynamics, is sex-specific $[19,23-26]$. In healthy subjects, circulating fatty acids are incorporated into triglycerides in women but oxidized in men [27]. Compared to men, healthy women have decreased free fatty acid-induced insulin resistance, lower circulating acylcarnitines and higher levels of sphingomyelins [3]. But, studies in healthy adults have little relevance to the critically ill. The hypercatabolism of critical illness substantially alters how oxidative fuel is produced from amino acids, fatty acids and carbohydrates [28]. The physiological stress of critical illness alters such energy metabolism changes in a sexspecific fashion [29]. Drug pharmacodynamics and pharmacokinetics variability is shown in critical illness but it is not yet known to be sex-specific [30].

In the sex-stratified analysis, we found that critically ill women differed from men in the patterns of change of free fatty acids with response to vitamin $D_{3}$. Specifically, with an increase in $25(\mathrm{OH}) \mathrm{D}$, circulating free fatty acids were lower and more significant within the male stratum (Figure 2). White adipose tissue is prominent in regulating metabolic homeostasis [31]. In healthy adults, sex-specific differences exist in the adipocyte cytokines adiponectin and leptin, with higher levels in women relative to men [32,33]. Experimental models show that vitamin $\mathrm{D}$ has a complex active role in adipose tissue metabolism by modifying inflammation and adipocyte secretory function [34]. Small human studies note that ceramide, the highly bioactive lipid mediator, may be regulated by vitamin $\mathrm{D}[35,36]$. Further study is needed to untangle the mechanism for the free fatty acid elevations noted in women responsive to vitamin D.

In the sex-stratified analysis, similar metabolomic patterns of change in the female and male strata are noted with higher levels of BCAA metabolites and plasmalogens and decreased levels of pentose phosphate pathway metabolites in response to increased $25(\mathrm{OH}) \mathrm{D}$ levels. These metabolite pathways are involved in bioenergesis, redox regulation and endothelial protection, respectively. During inflammation, amino acids are released into the circulation with protein breakdown. With inadequate mitochondrial fatty acid $\beta$-oxidation 
during critical illness, BCAAs are metabolized by the liver to high-energy compounds-a process that may be augmented by vitamin D signaling [37,38]. Plasmalogens are important antioxidants that act to protect endothelial cells from injury due to oxidative stress [39]. Pentose phosphate pathway metabolites increase with insufficient fatty acid $\beta$-oxidation, producing NADPH for redox regulation and ribose 5-phosphate for biosynthesis [40]. Our observation of lower levels of pentose phosphate pathway metabolites with increased $25(\mathrm{OH}) \mathrm{D}$ levels may be related to the induction of glutathione formation by vitamin $\mathrm{D}$, which provides cell and mitochondrial protection via lower ROS levels and lower NADPH demand $[10,41]$.

Fatty acid $\beta$-oxidation is the key pathway for fatty acid breakdown and energy production and is profoundly dysregulated in critical illness [42]. Fatty acid $\beta$-oxidation occurs in both mitochondria and peroxisomes. While long-, medium- and short-chain fatty acids are oxidized by mitochondria, very long-chain fatty acids, bile acids, branched-chain fatty acids and dicarboxylic fatty acids are oxidized by peroxisomes [43-45]. Vitamin D enhances fatty acid $\beta$-oxidation through upregulation of transcription factors, including PPAR $1 \alpha$ and the mitochondrial enzymes pyruvate dehydrogenase kinase 4 , as well as carnitine-palmitoyl transferase $1 \mathrm{a}$ and $1 \mathrm{~b}$ [46-48]. Further, data suggest that vitamin $\mathrm{D}$ is essential for mitochondrial oxidative phosphorylation capacity $[49,50]$.

In the sex-stratified analysis, we found that critically ill women and men differ in the patterns of change in acylcarnitines. Specifically, higher and more significant increases in long-chain acylcarnitines were present in the female stratum in response to increased 25(OH)D levels. Mitochondria in women utilize fatty acids over amino acids for energy production, create less reactive oxygen species and have an increased oxygen capacity compared to men [51-55]. Production of long-chain acylcarnitines occurs when elevated fatty acid supply exceeds mitochondrial oxidative capacity [56]. In exercise and insulin resistance, such mitochondrial overload is observed, resulting in elevated circulating longchain acylcarnitines [43,57]. The elevated long-chain acylcarnitines we observed in women are most likely due to increased fatty acid release that exceeds the oxidative capacity of mitochondria [56].

Important to the understanding of our observed long-chain acylcarnitine sex-specific response to vitamin $\mathrm{D}_{3}$ is the contribution of mitochondrial fatty acid uptake. The fatty acid transporter FAT/CD36 which facilitates fatty acid entry into mitochondria is shown to be more abundant in women [58-60]. FAT/CD36 abundance may be important for higher uptake of long-chain fatty acids by mitochondria in women [61]. Our observation of increased long-chain acylcarnitines in women relative to men following vitamin $\mathrm{D}_{3}$ may reflect an overwhelming of fatty acid $\beta$-oxidation by increased fatty acid delivery to mitochondria in women.

In the sex-stratified data, we find that BCAA catabolic metabolites increase in both men and women with increases in $25(\mathrm{OH}) \mathrm{D}$ levels. In our responder cohort analysis of the 153 patients who received and responded to high-dose vitamin $\mathrm{D}_{3}$, we observed that circulating BCAA catabolic metabolites and short-chain acylcarnitines were significantly lower in women relative to men. The relative decrease in even short-chain acylcarnitines (C4) in women is evidence of more complete fatty acid $\beta$-oxidation compared to men [43]. The $\mathrm{C} 3$ and $\mathrm{C} 5$ short-chain acylcarnitines are products of catabolism of BCAAs, threonine and methionine [62]. Our observed sex-specific differences in BCAA catabolic metabolites and short-chain acylcarnitines may reflect a greater enhancement of mitochondrial oxidative function in women with response to vitamin $\mathrm{D}_{3}$. Taken together, our results suggest that in the context of higher free fatty acids delivery, female mitochondria are more responsive to enhancement of mitochondrial oxidative function via vitamin $D_{3}$, which results in a lower relative production of short-chain acylcarnitines.

Our novel study approach has several strengths. The sample size was large and the repeated measurement of subjects over time substantially increases our statistical power $[37,63]$. Linear mixed models are useful for determination of metabolite abundance at multiple time points $[64,65]$. Furthermore, we adjusted for multiple comparisons using 
the false discovery rate [66]. Our work has potential limitations inherent to its metabolomics cohort study design. Specifically, as an observational study it is subject to bias and may have limited causal inference. The source of samples were White patients with serum $25(\mathrm{OH}) \mathrm{D} \leq 20 \mathrm{ng} / \mathrm{mL}$, so the results are potentially not generalizable to all critically ill patients.. Incomplete adjustment for the heterogeneity of illness may exist despite adjustment for demographics and clinical data. Though expression of 25-hydroxylase is not sex-specific, our use of $25(\mathrm{OH}) \mathrm{D}$ in determining absorption does not take into account potential differences in the activation of vitamin $\mathrm{D}_{3}$ in the liver $[67,68]$. It is important to note that our study is post hoc and should be considered hypothesis generating.

\section{Materials and Methods}

Detailed methods are presented in Supplemental Methods. In the VITdAL-ICU trial, 475 critically ill adults with serum 25-hydroxyvitamin D [25(OH)D] $\leq 20 \mathrm{ng} / \mathrm{mL}$ were randomized to oral- or nasogastric tube-administered vitamin $\mathrm{D}_{3}$ 540,000 IU followed by 90,000 IU monthly or placebo (oleum arachidis) [20]. Trial inclusion criteria included patients admitted to a medical or surgical ICU who were 18 years or older with an expected ICU stay of $\geq 48 \mathrm{~h}$ and a $25(\mathrm{OH}) \mathrm{D}$ level of $20 \mathrm{ng} / \mathrm{mL}$ or lower. Excluded from the trial were: patients with severely impaired gastrointestinal function; other trial participation; pregnancy; lactating women; tuberculosis; sarcoidosis; hypercalcemia; nephrolithiasis in the past year; and patients not deemed suitable for study participation (i.e., psychiatric disease, prisoner status). Blood samples were collected on days 0 (at randomization), 3 and 7. Plasma was fractionated, aliquoted and stored at $-80^{\circ} \mathrm{C}$. Frozen plasma was available in 453 VITdAL-ICU trial subjects, of whom 25 were excluded due to absence of serum $25(\mathrm{OH}) \mathrm{D}$ determination at day 3.

For determination of the pharmacokinetics of oral vitamin $\mathrm{D}_{3}$, we utilized serum $25(\mathrm{OH}) \mathrm{D}$ levels, a marker of systemic vitamin D status [69]. Serum 25(OH)D levels were determined via chemiluminescence assay (IDS-iSYS, Immunodiagnostic Systems) with assay coefficients of variation for control material of $9.4 \%$ at $64 \mathrm{ng} / \mathrm{mL}, 10 \%$ at $31 \mathrm{ng} / \mathrm{mL}$ and $13.4 \%$ at $13 \mathrm{ng} / \mathrm{mL}$ [20]. For pharmacokinetics evaluation, the area under the plasma concentration-time curve from vitamin $\mathrm{D}_{3}$ dosing to day 7 (AUC0-7d) was calculated using the linear trapezoidal method. Patients with missing $25(\mathrm{OH}) \mathrm{D}$ levels on day 3 or 7 and those who received placebo were excluded from the pharmacokinetics evaluation. AUC normalized to vitamin $\mathrm{D}_{3}$ dose and body weight (AUCnorm) was calculated by dividing AUC0-7d by dose in IU per kg body weight. Median AUCnorm and serum 25(OH)D levels on days 0,3 and 7 values were compared between males and females.

Metabolomics data was produced from 1215 plasma samples obtained from 428 patients: 428 samples were analyzed from day 0, 413 at day 3 and 374 at day 7 . Four ultra-high-performance liquid chromatography/tandem accurate mass spectrometry (UHPLC/MS/MS) methods were utilized by Metabolon, Inc. (Morrisville, NC, USA) to identify 983 metabolites [18,29]. We cube root-transformed and Pareto-scaled the metabolomics data to generate an approximate normal distribution.

Based on our previous metabolomics analysis of the VITdAL-ICU trial [18], we considered a response to high-dose oral vitamin $\mathrm{D}_{3}$ as an absolute increase in $25(\mathrm{OH}) \mathrm{D} \geq 7.5$ $\mathrm{ng} / \mathrm{mL}$ from day 0 to day 3 . For a sex-stratified analysis of day 0 data, we utilized the Student's $t$-test to determine the significance of individual metabolites between vitamin $\mathrm{D}_{3}$ response groups $(25(\mathrm{OH}) \mathrm{D}<$ or $\geq 7.5 \mathrm{ng} / \mathrm{mL}$ from day 0 to day 3) using MetaboAnalyst in women and in men [70]. We corrected for multiple testing via the Benjamini-Hochberg procedure to adjust the false discovery rate (FDR) to 0.10 , producing a $q$-value [66]. We analyzed sex-stratified day 0 data via orthogonal partial least squares-discriminant analysis (OPLS-DA), a statistical method for supervised classification discrimination (SIMCA 15.0 Umetrics, Umea, Sweden). We utilized the OPLS-DA approach to find the metabolomic differences at baseline (day 0 ) between patients who did and did not respond to high-dose vitamin $\mathrm{D}_{3}$. We analyzed male and female subjects separately to determine if such differences in metabolites at baseline were sex-specific. We used goodness of fit (R2) and 
predictive performance $(\mathrm{Q} 2)$ to describe the OPLS-DA model quality. To validate the OPLSDA model, we performed permutation testing. To determine overall OPLS-DA model significance, we used sevenfold cross-validation analysis of variance (CV-ANOVA).

For day 0,3 and 7 repeated measures data, correlations between individual metabolites and absolute increase in $25(\mathrm{OH}) \mathrm{D}$ levels from day 0 to day 3 were determined separately in women and in men utilizing sex-stratified linear mixed effects models correcting for age, baseline $25(\mathrm{OH}) \mathrm{D}$, SAPS II, sample day, admission diagnosis, and a subject-specific random intercept. A false discovery rate adjusted $p$-value ( $q$-value) threshold of 0.10 was utilized to identify all significant differences [66]. Additionally, we performed a sub-analysis in a responder cohort of patients who received high-dose vitamin $\mathrm{D}_{3}$ intervention and had an increase in $25(\mathrm{OH}) \mathrm{D} \geq 7.5 \mathrm{ng} / \mathrm{mL}$ from day 0 to day 3 . For day 0,3 and 7 repeated measures data, we determined correlations between individual metabolites over time relative to sex (as the exposure) using linear mixed effects models adjusted for age, baseline 25(OH)D, SAPS II, sample day, admission diagnosis and a subject-specific random intercept. All mixed effects models were analyzed using STATA 16.1 (College Station, TX, USA). For data visualization purposes, rain plots were produced in R-3.6.2 [71].

Lastly, we evaluated a potential sex-specific mediating effect on the association between the absolute rise in $25(\mathrm{OH}) \mathrm{D}$ levels from day 0 to day 3 and individual metabolite abundance, adjusting for baseline $25(\mathrm{OH}) \mathrm{D}$, age, SAPS II and diagnosis at admission. Each of the 983 metabolites at day 3 were analyzed using mediation, an $\mathrm{R}$ package for causal mediation analysis [72], to determine bootstrap $p$-values $(\mathrm{N}=2000)$ for the sex-specific mediating effect. Mediation was significantly present if $\geq 10 \%$ of the association was mediated through sex and the $p$-value was $<0.01$ [73].

\section{Conclusions}

In a large metabolomics study, we demonstrated substantial differences between women and men in the response to high-dose vitamin $\mathrm{D}_{3}$ early in critical illness. Specifically, robust sex-specific differences in pharmacokinetics and metabolomics were found in the response over time to high-dose vitamin $\mathrm{D}_{3}$. Demonstrating sex-specific differences in the metabolic response to pharmacologic intervention is a crucial first step in the understanding of personalized medicine.

Supplementary Materials: The following are available online at https://www.mdpi.com/article/ 10.3390/metabo12030207/s1, Figure S1: Day 0, 3 and 7 serum 25(OH)D levels in women and men. Whisker and box plot overlaid with a dot plot showing median and quartile values of the 25(OH)D at day 0,3 and 7 in women $(N=78)$ and men $(N=134)$, randomized to vitamin $D_{3}$, Figure S2: Responder cohort short-chain acylcarnitines. Day 0, 3 and 7 short-chain acylcarnitines in the 153-patient responder cohort (those who received high-dose vitamin $\mathrm{D}_{3}$ intervention and had an increase in $25(\mathrm{OH}) \mathrm{D}$ $\geq 7.5 \mathrm{ng} / \mathrm{mL}$ ), Figure S3: Responder cohort BCAA metabolites. Day 0, 3 and 7 BCAA metabolites in the 153-patient responder cohort (those who received high-dose vitamin $\mathrm{D}_{3}$ intervention and had an increase in $25(\mathrm{OH}) \mathrm{D} \geq 7.5 \mathrm{ng} / \mathrm{mL}$ ), Table S1: Pharmacokinetics of high-dose vitamin $\mathrm{D}_{3}$, Table S2: Day $0 t$-test in female and male subjects. Significance of individual metabolites in subjects with an absolute increase of $25(\mathrm{OH}) \mathrm{D}<$ or $\geq 7.5 \mathrm{ng} / \mathrm{mL}$ from day 0 to day 3 as determined by $t$-test adjusted for false discovery rate, Table S3: OPLS-DA model goodness of fit and predictive ability, Table S4: Sex-stratified mixed effects regression, Table S5: Sex-stratified mixed effects regression model with additional adjustment for the Charlson Comorbidity Index, Table S6: Responder cohort mixed effects regression, Table S7: Responder cohort mixed effects regression model with additional adjustment for the Charlson Comorbidity Index, Methods S1: Details regarding the VITdAL-ICU clinical trial, sample preparation, quality assurance and quality control, ultrahigh performance liquid chromatography-tandem mass spectroscopy, data extraction and compound identification, curation, metabolite quantification and data normalization, pharmacokinetics and statistical analyses, Data S1: Details of the 983 metabolites analyzed, including biochemical name, retention time, mass-tocharge ratio, metabolic pathway, analysis platform, Chemical Abstracts Service number, PUBCHEM identifier, KEGG pathway and HMDB ID. 


\begin{abstract}
Author Contributions: Conceptualization, S.C., K.A., J.A.L.-S. and K.B.C.; methodology, S.C., S.H.M., J.A.L.-S. and K.B.C.; software, K.B.C.; validation, S.C., K.A., and K.B.C.; formal analysis, S.C. and K.B.C.; investigation, S.C., K.A., S.H.M. and K.B.C.; resources, K.B.C.; data curation, K.A. and K.B.C.; writing-original draft preparation, S.C., K.A., S.H.M., J.L-S. and K.B.C.; writing-review and editing, S.C., K.A. and K.B.C.; visualization, S.C. and K.B.C.; supervision, K.B.C.; project administration, K.A. and K.B.C.; funding acquisition, K.A. and K.B.C. All authors have read and agreed to the published version of the manuscript.
\end{abstract}

Funding: This research was funded by the National Institutes of Health grant number R01 GM115774. The VITdAL-ICU trial was supported by the European Society for Clinical Nutrition and Metabolism (ESPEN), a research grant including provision of study medication from Fresenius Kabi (Germany) and the Austrian National Bank (Jubiläumsfonds, Project Nr. 14143). The APC was funded by Medizinischen Universität Graz.

Institutional Review Board Statement: The study was conducted according to the guidelines of the Declaration of Helsinki and approved by Mass General Brigham Human Research Committee (Protocol 2015P002766 in February 2016) and the Ethikkommission der Medizinischen Universität Graz, Austria (Ethikkommission number 21-214 in September 2010).

Informed Consent Statement: Informed consent was obtained from all subjects involved in the study. At VITdAL-ICU trial enrollment, written informed consent was obtained, if possible, directly from the patient or from a legal surrogate. Consent included permission for plasma specimens to be saved for future research studies.

Data Availability Statement: The data presented in this study are available in Tables S1-S7.

Acknowledgments: This article is dedicated to the memory of our dear friend and colleague Nathan Edward Hellman.

Conflicts of Interest: S. Chary was a master's student at Harvard Medical School during the implementation of the study. During her master's, S. Chary was employed at Takeda Pharmaceutical Company and is currently employed by Biogen, Inc. S. Chary reports receiving salary and stock options from Takeda and from Biogen. Neither Takeda nor Biogen had any involvement in the VITdAL-ICU trial, the identification of metabolites, the post hoc study design, the analysis of metabolomics, interpretation of the data, access to the data or the writing of the manuscript. $\mathrm{K}$. Amrein reports receiving lecture fees from Fresenius Kabi. No other financial or other relationships exist that might lead to a conflict of interest.

\title{
References
}

1. Gandhi, M.; Aweeka, F.; Greenblatt, R.M.; Blaschke, T.F. Sex differences in pharmacokinetics and pharmacodynamics. Annu. Rev. Pharm. Toxicol. 2004, 44, 499-523. [CrossRef] [PubMed]

2. Kolz, M.; Johnson, T.; Sanna, S.; Teumer, A.; Vitart, V.; Perola, M.; Mangino, M.; Albrecht, E.; Wallace, C.; Farrall, M.; et al. Meta-analysis of 28,141 individuals identifies common variants within five new loci that influence uric acid concentrations. PLoS Genet 2009, 5, e1000504. [CrossRef] [PubMed]

3. Mittelstrass, K.; Ried, J.S.; Yu, Z.; Krumsiek, J.; Gieger, C.; Prehn, C.; Roemisch-Margl, W.; Polonikov, A.; Peters, A.; Theis, F.J.; et al. Discovery of sexual dimorphisms in metabolic and genetic biomarkers. PLoS Genet 2011, 7, e1002215. [CrossRef] [PubMed]

4. $\quad$ Dunn, W.B.; Lin, W.; Broadhurst, D.; Begley, P.; Brown, M.; Zelena, E.; Vaughan, A.A.; Halsall, A.; Harding, N.; Knowles, J.D.; et al. Molecular phenotyping of a UK population: Defining the human serum metabolome. Metabolomics 2015, 11, 9-26. [CrossRef]

5. Franconi, F.; Campesi, I. Sex Impact on Biomarkers, Pharmacokinetics and Pharmacodynamics. Curr. Med. Chem. 2017, 24, 2561-2575. [CrossRef]

6. Kantae, V.; Krekels, E.H.J.; Esdonk, M.J.V.; Lindenburg, P.; Harms, A.C.; Knibbe, C.A.J.; Van der Graaf, P.H.; Hankemeier, T. Integration of pharmacometabolomics with pharmacokinetics and pharmacodynamics: Towards personalized drug therapy. Metabolomics 2017, 13, 9. [CrossRef]

7. Karlsson Lind, L.; von Euler, M.; Korkmaz, S.; Schenck-Gustafsson, K. Sex differences in drugs: The development of a comprehensive knowledge base to improve gender awareness prescribing. Biol. Sex Differ. 2017, 8, 32. [CrossRef]

8. Kiehntopf, M.; Nin, N.; Bauer, M. Metabolism, metabolome, and metabolomics in intensive care: Is it time to move beyond monitoring of glucose and lactate? Am. J. Respir. Crit. Care Med. 2013, 187, 906-907. [CrossRef]

9. Johansson, P.I.; Nakahira, K.; Rogers, A.J.; McGeachie, M.J.; Baron, R.M.; Fredenburgh, L.E.; Harrington, J.; Choi, A.M.K.; Christopher, K.B. Plasma mitochondrial DNA and metabolomic alterations in severe critical illness. Crit. Care 2018, 22, 360. [CrossRef] 
10. Lasky-Su, J.; Dahlin, A.; Litonjua, A.A.; Rogers, A.J.; McGeachie, M.J.; Baron, R.M.; Gazourian, L.; Barragan-Bradford, D.; Fredenburgh, L.E.; Choi, A.M.K.; et al. Metabolome alterations in severe critical illness and vitamin D status. Crit. Care 2017, 21, 193. [CrossRef]

11. Dupuis, M.L.; Pagano, M.T.; Pierdominici, M.; Ortona, E. The role of vitamin D in autoimmune diseases: Could sex make the difference? Biol. Sex Differ. 2021, 12, 12. [CrossRef] [PubMed]

12. Sanghera, D.K.; Sapkota, B.R.; Aston, C.E.; Blackett, P.R. Vitamin D Status, Gender Differences, and Cardiometabolic Health Disparities. Ann. Nutr. Metab. 2017, 70, 79-87. [CrossRef] [PubMed]

13. Ilahi, M.; Armas, L.A.; Heaney, R.P. Pharmacokinetics of a single, large dose of cholecalciferol. Am. J. Clin. Nutr. 2008, 87, 688-691. [CrossRef] [PubMed]

14. Romagnoli, E.; Mascia, M.L.; Cipriani, C.; Fassino, V.; Mazzei, F.; D’Erasmo, E.; Carnevale, V.; Scillitani, A.; Minisola, S. Short and long-term variations in serum calciotropic hormones after a single very large dose of ergocalciferol (vitamin D2) or cholecalciferol (vitamin D3) in the elderly. J. Clin. Endocrinol. Metab. 2008, 93, 3015-3020. [CrossRef]

15. Cipriani, C.; Romagnoli, E.; Scillitani, A.; Chiodini, I.; Clerico, R.; Carnevale, V.; Mascia, M.L.; Battista, C.; Viti, R.; Pileri, M.; et al. Effect of a single oral dose of $600,000 \mathrm{IU}$ of cholecalciferol on serum calciotropic hormones in young subjects with vitamin D deficiency: A prospective intervention study. J. Clin. Endocrinol. Metab. 2010, 95, 4771-4777. [CrossRef]

16. Sanders, K.M.; Stuart, A.L.; Williamson, E.J.; Simpson, J.A.; Kotowicz, M.A.; Young, D.; Nicholson, G.C. Annual high-dose oral vitamin D and falls and fractures in older women: A randomized controlled trial. JAMA 2010, 303, 1815-1822. [CrossRef]

17. Kaddurah-Daouk, R.; Kristal, B.S.; Weinshilboum, R.M. Metabolomics: A global biochemical approach to drug response and disease. Annu. Rev. Pharmacol. Toxicol. 2008, 48, 653-683. [CrossRef]

18. Amrein, K.; Lasky-Su, J.A.; Dobnig, H.; Christopher, K.B. Metabolomic basis for response to high dose vitamin D in critical illness. Clin. Nutr. 2021, 40, 2053-2060. [CrossRef]

19. Soldin, O.P.; Mattison, D.R. Sex differences in pharmacokinetics and pharmacodynamics. Clin. Pharm. 2009, 48, 143-157. [CrossRef]

20. Amrein, K.; Schnedl, C.; Holl, A.; Riedl, R.; Christopher, K.B.; Pachler, C.; Urbanic Purkart, T.; Waltensdorfer, A.; Munch, A.; Warnkross, H.; et al. Effect of high-dose vitamin D3 on hospital length of stay in critically ill patients with vitamin D deficiency: The VITdAL-ICU randomized clinical trial. JAMA 2014, 312, 1520-1530. [CrossRef]

21. Fong, Y.M.; Marano, M.A.; Moldawer, L.L.; Wei, H.; Calvano, S.E.; Kenney, J.S.; Allison, A.C.; Cerami, A.; Shires, G.T.; Lowry, S.F. The acute splanchnic and peripheral tissue metabolic response to endotoxin in humans. J. Clin. Investg. 1990, 85, 1896-1904. [CrossRef]

22. Boden, G. Obesity and free fatty acids. Endocrinol. Metab. Clin. N. Am. 2008, 37, 635-646. [CrossRef]

23. Murphy, M.O.; Loria, A.S. Sex-specific effects of stress on metabolic and cardiovascular disease: Are women at higher risk? Am. J. Physiol. Regul. Integr. Comp. Physiol. 2017, 313, R1-R9. [CrossRef] [PubMed]

24. Mauvais-Jarvis, F. Sex differences in metabolic homeostasis, diabetes, and obesity. Biol. Sex Differ. 2015, 6, 14. [CrossRef] [PubMed]

25. Roeters van Lennep, J.E.; Westerveld, H.T.; Erkelens, D.W.; van der Wall, E.E. Risk factors for coronary heart disease: Implications of gender. Cardiovasc. Res. 2002, 53, 538-549. [CrossRef]

26. Sugiyama, M.G.; Agellon, L.B. Sex differences in lipid metabolism and metabolic disease risk. Biochem. Cell Biol. 2012, 90, $124-141$. [CrossRef]

27. Uranga, A.P.; Levine, J.; Jensen, M. Isotope tracer measures of meal fatty acid metabolism: Reproducibility and effects of the menstrual cycle. Am. J. Physiol. Endocrinol. Metab. 2005, 288, E547-E555. [CrossRef]

28. Preiser, J.C.; Ichai, C.; Orban, J.C.; Groeneveld, A.B. Metabolic response to the stress of critical illness. Br. J. Anaesth. 2014, 113, 945-954. [CrossRef] [PubMed]

29. Chary, S.; Amrein, K.; Lasky-Su, J.; Dobnig, H.; Christopher, K.B. The Sex-specific Metabolic Response to Critical Illness: A post-hoc metabolomics study of the VITdAL-ICU trial. Sci. Rep. 2021, 11, 3951. [CrossRef]

30. Blot, S.I.; Pea, F.; Lipman, J. The effect of pathophysiology on pharmacokinetics in the critically ill patient-concepts appraised by the example of antimicrobial agents. Adv. Drug Deliv. Rev. 2014, 77, 3-11. [CrossRef]

31. Stern, J.H.; Rutkowski, J.M.; Scherer, P.E. Adiponectin, Leptin, and Fatty Acids in the Maintenance of Metabolic Homeostasis through Adipose Tissue Crosstalk. Cell Metab. 2016, 23, 770-784. [CrossRef] [PubMed]

32. Laughlin, G.A.; Barrett-Connor, E.; May, S. Sex-specific determinants of serum adiponectin in older adults: The role of endogenous sex hormones. Int. J. Obes. 2007, 31, 457-465. [CrossRef] [PubMed]

33. Kennedy, A.; Gettys, T.W.; Watson, P.; Wallace, P.; Ganaway, E.; Pan, Q.; Garvey, W.T. The metabolic significance of leptin in humans: Gender-based differences in relationship to adiposity, insulin sensitivity, and energy expenditure. J. Clin. Endocrinol. Metab. 1997, 82, 1293-1300. [CrossRef] [PubMed]

34. Mutt, S.J.; Hypponen, E.; Saarnio, J.; Jarvelin, M.R.; Herzig, K.H. Vitamin D and adipose tissue-more than storage. Front. Physiol. 2014, 5, 228. [CrossRef] [PubMed]

35. Chen, L.; Dong, Y.; Bhagatwala, J.; Raed, A.; Huang, Y.; Zhu, H. Vitamin D3 Supplementation Increases Long-Chain Ceramide Levels in Overweight/Obese African Americans: A Post-Hoc Analysis of a Randomized Controlled Trial. Nutrients 2020, $12,981$. [CrossRef] 
36. Koch, A.; Grammatikos, G.; Trautmann, S.; Schreiber, Y.; Thomas, D.; Bruns, F.; Pfeilschifter, J.; Badenhoop, K.; Penna-Martinez, M. Vitamin D Supplementation Enhances C18(dihydro)ceramide Levels in Type 2 Diabetes Patients. Int. J. Mol. Sci. 2017, 18, 1532. [CrossRef]

37. Kobayashi, H.; Amrein, K.; Lasky-Su, J.; Christopher, K.B. Procalcitonin Metabolomics in the Critically Ill reveal relationships between inflammation intensity and energy utilization pathways. Sci. Rep. 2021, 11, 23194. [CrossRef]

38. Dimitrov, V.; Barbier, C.; Ismailova, A.; Wang, Y.; Dmowski, K.; Salehi-Tabar, R.; Memari, B.; Groulx-Boivin, E.; White, J.H. Vitamin D-regulated Gene Expression Profiles: Species-specificity and Cell-specific Effects on Metabolism and Immunity. Endocrinology 2021, 162. [CrossRef]

39. Wallner, S.; Schmitz, G. Plasmalogens the neglected regulatory and scavenging lipid species. Chem. Phys. Lipids 2011, 164, 573-589. [CrossRef]

40. Nalos, M.; Parnell, G.; Robergs, R.; Booth, D.; McLean, A.S.; Tang, B.M. Transcriptional reprogramming of metabolic pathways in critically ill patients. Intensive Care Med. Exp. 2016, 4, 21. [CrossRef]

41. Jain, S.K.; Micinski, D. Vitamin D upregulates glutamate cysteine ligase and glutathione reductase, and GSH formation, and decreases ROS and MCP-1 and IL-8 secretion in high-glucose exposed U937 monocytes. Biochem. Biophys. Res. Commun. 2013, 437, 7-11. [CrossRef] [PubMed]

42. Langley, R.J.; Tsalik, E.L.; van Velkinburgh, J.C.; Glickman, S.W.; Rice, B.J.; Wang, C.; Chen, B.; Carin, L.; Suarez, A.; Mohney, R.P.; et al. An integrated clinico-metabolomic model improves prediction of death in sepsis. Sci. Transl. Med. 2013, 5, 195ra195. [CrossRef] [PubMed]

43. Koves, T.R.; Ussher, J.R.; Noland, R.C.; Slentz, D.; Mosedale, M.; Ilkayeva, O.; Bain, J.; Stevens, R.; Dyck, J.R.; Newgard, C.B.; et al. Mitochondrial overload and incomplete fatty acid oxidation contribute to skeletal muscle insulin resistance. Cell Metab. 2008, 7, 45-56. [CrossRef] [PubMed]

44. Makrecka-Kuka, M.; Sevostjanovs, E.; Vilks, K.; Volska, K.; Antone, U.; Kuka, J.; Makarova, E.; Pugovics, O.; Dambrova, M.; Liepinsh, E. Plasma acylcarnitine concentrations reflect the acylcarnitine profile in cardiac tissues. Sci. Rep. 2017, 7, 17528. [CrossRef]

45. Violante, S.; Ijlst, L.; Te Brinke, H.; Koster, J.; Tavares de Almeida, I.; Wanders, R.J.; Ventura, F.V.; Houten, S.M. Peroxisomes contribute to the acylcarnitine production when the carnitine shuttle is deficient. Biochim. Biophys. Acta 2013, 1831, 1467-1474. [CrossRef]

46. Yin, Y.; Yu, Z.; Xia, M.; Luo, X.; Lu, X.; Ling, W. Vitamin D attenuates high fat diet-induced hepatic steatosis in rats by modulating lipid metabolism. Eur. J. Clin. Investig. 2012, 42, 1189-1196. [CrossRef]

47. Marcotorchino, J.; Tourniaire, F.; Astier, J.; Karkeni, E.; Canault, M.; Amiot, M.J.; Bendahan, D.; Bernard, M.; Martin, J.C.; Giannesini, B.; et al. Vitamin D protects against diet-induced obesity by enhancing fatty acid oxidation. J. Nutr. Biochem. 2014, 25, 1077-1083. [CrossRef]

48. Sergeev, I.N.; Song, Q. High vitamin D and calcium intakes reduce diet-induced obesity in mice by increasing adipose tissue apoptosis. Mol. Nutr. Food Res. 2014, 58, 1342-1348. [CrossRef]

49. Latham, C.M.; Brightwell, C.R.; Keeble, A.R.; Munson, B.D.; Thomas, N.T.; Zagzoog, A.M.; Fry, C.S.; Fry, J.L. Vitamin D Promotes Skeletal Muscle Regeneration and Mitochondrial Health. Front. Physiol. 2021, 12, 660498. [CrossRef]

50. Sinha, A.; Hollingsworth, K.G.; Ball, S.; Cheetham, T. Improving the vitamin D status of vitamin D deficient adults is associated with improved mitochondrial oxidative function in skeletal muscle. J. Clin. Endocrinol. Metab. 2013, 98, E509-E513. [CrossRef]

51. Ventura-Clapier, R.; Moulin, M.; Piquereau, J.; Lemaire, C.; Mericskay, M.; Veksler, V.; Garnier, A. Mitochondria: A central target for sex differences in pathologies. Clin. Sci. 2017, 131, 803-822. [CrossRef] [PubMed]

52. Malorni, W.; Campesi, I.; Straface, E.; Vella, S.; Franconi, F. Redox features of the cell: A gender perspective. Antioxid. Redox Signal. 2007, 9, 1779-1801. [CrossRef] [PubMed]

53. Vina, J.; Borras, C. Women live longer than men: Understanding molecular mechanisms offers opportunities to intervene by using estrogenic compounds. Antioxid. Redox Signal. 2010, 13, 269-278. [CrossRef] [PubMed]

54. Demarest, T.G.; McCarthy, M.M. Sex differences in mitochondrial (dys)function: Implications for neuroprotection. J. Bioenerg. Biomembr. 2015, 47, 173-188. [CrossRef]

55. Austad, S.N.; Fischer, K.E. Sex Differences in Lifespan. Cell Metab. 2016, 23, 1022-1033. [CrossRef]

56. Bruls, Y.M.; de Ligt, M.; Lindeboom, L.; Phielix, E.; Havekes, B.; Schaart, G.; Kornips, E.; Wildberger, J.E.; Hesselink, M.K.; Muoio, D.; et al. Carnitine supplementation improves metabolic flexibility and skeletal muscle acetylcarnitine formation in volunteers with impaired glucose tolerance: A randomised controlled trial. EBioMedicine 2019, 49, 318-330. [CrossRef]

57. Zhang, J.; Light, A.R.; Hoppel, C.L.; Campbell, C.; Chandler, C.J.; Burnett, D.J.; Souza, E.C.; Casazza, G.A.; Hughen, R.W.; Keim, N.L.; et al. Acylcarnitines as markers of exercise-associated fuel partitioning, xenometabolism, and potential signals to muscle afferent neurons. Exp. Physiol. 2017, 102, 48-69. [CrossRef]

58. Holloway, G.P.; Bezaire, V.; Heigenhauser, G.J.; Tandon, N.N.; Glatz, J.F.; Luiken, J.J.; Bonen, A.; Spriet, L.L. Mitochondrial long chain fatty acid oxidation, fatty acid translocase/CD36 content and carnitine palmitoyltransferase I activity in human skeletal muscle during aerobic exercise. J. Physiol. 2006, 571, 201-210. [CrossRef]

59. Bezaire, V.; Bruce, C.R.; Heigenhauser, G.J.; Tandon, N.N.; Glatz, J.F.; Luiken, J.J.; Bonen, A.; Spriet, L.L. Identification of fatty acid translocase on human skeletal muscle mitochondrial membranes: Essential role in fatty acid oxidation. Am. J. Physiol. Endocrinol. Metab. 2006, 290, E509-E515. [CrossRef] 
60. Kiens, B.; Roepstorff, C.; Glatz, J.F.; Bonen, A.; Schjerling, P.; Knudsen, J.; Nielsen, J.N. Lipid-binding proteins and lipoprotein lipase activity in human skeletal muscle: Influence of physical activity and gender. J. Appl. Physiol. 2004, 97, 1209-1218. [CrossRef]

61. Maher, A.C.; Akhtar, M.; Vockley, J.; Tarnopolsky, M.A. Women have higher protein content of beta-oxidation enzymes in skeletal muscle than men. PLoS ONE 2010, 5, e12025. [CrossRef] [PubMed]

62. Newgard, C.B. Interplay between lipids and branched-chain amino acids in development of insulin resistance. Cell Metab. 2012, 15, 606-614. [CrossRef] [PubMed]

63. Vickers, A.J. How many repeated measures in repeated measures designs? Statistical issues for comparative trials. BMC Med. Res. Methodol. 2003, 3, 22. [CrossRef] [PubMed]

64. Mei, Y.; Kim, B.S.; Tsui, K. Linear mixed effects models for feature selection in high dimensional NMR spectra. Exprt Syst. Applic. 2009, 36, 4703-4708. [CrossRef]

65. Ernest, B.; Gooding, J.R.; Campagna, S.R.; Saxton, A.M.; Voy, B.H. MetabR: An R script for linear model analysis of quantitative metabolomic data. BMC Res. Notes 2012, 5, 596. [CrossRef]

66. Benjamini, Y.; Yekutieli, D. The control of the false discovery rate in multiple testing under dependency. Ann. Stat. 2001, 29, 1165-1188. [CrossRef]

67. Cheng, J.B.; Motola, D.L.; Mangelsdorf, D.J.; Russell, D.W. De-orphanization of cytochrome P450 2R1: A microsomal vitamin D 25-hydroxilase. J. Biol. Chem. 2003, 278, 38084-38093. [CrossRef]

68. Yamasaki, T.; Izumi, S.; Ide, H.; Ohyama, Y. Identification of a novel rat microsomal vitamin D3 25-hydroxylase. J. Biol. Chem. 2004, 279, 22848-22856. [CrossRef]

69. Seamans, K.M.; Cashman, K.D. Existing and potentially novel functional markers of vitamin D status: A systematic review. Am. J. Clin. Nutr. 2009, 89, 1997S-2008S. [CrossRef]

70. Chong, J.; Xia, J. Using MetaboAnalyst 4.0 for Metabolomics Data Analysis, Interpretation, and Integration with Other Omics Data. Methods Mol. Biol. 2020, 2104, 337-360. [CrossRef]

71. Henglin, M.; Niiranen, T.; Watrous, J.D.; Lagerborg, K.A.; Antonelli, J.; Claggett, B.L.; Demosthenes, E.J.; von Jeinsen, B.; Demler, O.; Vasan, R.S.; et al. A Single Visualization Technique for Displaying Multiple Metabolite-Phenotype Associations. Metabolites 2019, 9, 128. [CrossRef] [PubMed]

72. Dustin, T.; Yamamoto, T.; Hirose, K.; Keele, L.; Imai, K. mediation: R package for causal mediation analysis. J. Stat. Softw. 2014, 59, 1-38.

73. Pietzner, M.; Budde, K.; Homuth, G.; Kastenmuller, G.; Henning, A.K.; Artati, A.; Krumsiek, J.; Volzke, H.; Adamski, J.; Lerch, M.M.; et al. Hepatic Steatosis Is Associated with Adverse Molecular Signatures in Subjects Without Diabetes. J. Clin. Endocrinol. Metab. 2018, 103, 3856-3868. [CrossRef] [PubMed] 